\title{
MOESSBAUER SPECTROSCOPIC, CHEMICAL AND MINERALOGICAL CHARACTERIZATION OF IBERIAN POTTERY
}

\author{
J.R. GANCEDO, M. GRACIA \\ Instituto de Quimica Fisica 'Rocasolano' C.S.I.C., C/Serrano 119, Madrid-6, Spain \\ A. HERNANDEZ-LAGUNA,C.RUIZ-GARCIA \\ Instituto Geológico y Minero de España, C/Rios Rosas 23, Madrid-3, Spain \\ and J. PALOMARES \\ J.E.N. Ciudad Universitaria, Madrid-3, Spain
}

\section{INTRODUCTION}

Characterization of ancient pottery is threefold: the provenance of the clay, non-plastics added and firing technology (kiln atmosphere and associated thermal cycle).

Very often sherds of different provenance have similar appearance although, conversely, different manufacturing techniques can produce a wide variety of pottery from the same clay. Therefore a classification of the sherds based solely upon macroscopic and stylistic grounds could lead to serious mistakes. Physicochemical techniques could contribute more substantial evidence.

The subject of this study is lberian pottery. The sherds studied belong to the same archaeological level (fourth century B.C.) of Lora del Río (Seville) excavation. In this level three well differentiated pottery types are found:

(1) 'Painted' pottery ('P') which was thrown, leather coloured and painted with reddish stripes.

(2) 'Grey' pottery ('G') which was thrown, grey coloured and had a smooth finish.

(3) 'Handmade' pottery ('H') which had a rough appearance, large inclusions, and a colour varying from yellowish to reddish.

In this work we have tried to identify the general aspects of the fabrication technique. For this purpose the following techniques were used: mineralogical analyses by X-ray powder diffractography (XRD) and transmitted-light microscopy, atomic absorption spectroscopy (AAS) for estimation of $\mathrm{Ca}, \mathrm{Na}, \mathrm{K}, \mathrm{Mg}, \mathrm{Fe}$ and $\mathrm{Al}$, and Moessbauer spectroscopy (MS) for studying the environment and oxidation state of the iron in the pottery.

\section{EXPERIMENTAL}

The XRD was performed with a Philips diffractometer, model PW 1130/00, and a goniometer, model PW 1050/25. The $\mathrm{Cu}_{\alpha}$ radiation was obtained by exciting at $40 \mathrm{kV}$ and $40 \mathrm{~mA}$.

Polarized transmitted-light studies involved a Leitz microscope, model Orthoplan.

The AAS was performed with a Perkin Elmer spectrometer, model 360. 
Table 1 AAS analysis

\begin{tabular}{lrrr}
\hline \hline & $\begin{array}{c}\text { 'P' pottery } \\
\text { (5 samples) }\end{array}$ & $\begin{array}{c}\text { 'G' pottery } \\
\text { (5 samples) }\end{array}$ & $\begin{array}{r}\text { ' } H^{\prime} \text { pottery } \\
\text { (5 samples) }\end{array}$ \\
\hline$\% \mathrm{CaO}$ & $7.2 \pm 1.3$ & $7.3 \pm 1.3$ & $1.5 \pm 0.9$ \\
$\% \mathrm{Na}_{2} \mathrm{O}$ & $0.8 \pm 0.1$ & $0.9 \pm 0.1$ & $2.7 \pm 1.4$ \\
$\% \mathrm{~K}_{2} \mathrm{O}$ & $2.8 \pm 0.1$ & $2.7 \pm 0.1$ & $2.7 \pm 1.0$ \\
$\% \mathrm{MgO}_{\% \mathrm{Fe}_{2} \mathrm{O}_{3}}$ & $2.0 \pm 0.2$ & $2.0 \pm 0.2$ & $2.2 \pm 1.3$ \\
$\% \mathrm{Al}_{2} \mathrm{O}_{3}$ & $5.7 \pm 0.3$ & $5.7 \pm 0.3$ & $6.4 \pm 1.0$ \\
\hline
\end{tabular}

Moessbauer spectra (MS) in transmission mode were recorded with a laboratory-made acceleration spectrograph. The spectra obtained were computer-fitted to a sum of Lorentzian lines. The powder samples had a thickness corresponding to $5 \mathrm{mg} / \mathrm{cm}^{2}$ of natural iron.

\section{RESULTS AND DISCUSSION}

The results of AAS (table 1) suggest that the ' $\mathrm{P}$ ' and ' $\mathrm{G}$ ' pottery was made with calcareous clay, had similar refractory properties, and possibly had the same provenance. The results for the five hand-made ceramics indicate the use of a non-calcareous clay but also show a much wider spread in composition, probably because large inclusions in the clay matrix prevent the taking of homogeneous samples.

Part of the MS study has been published (Gancedo, Gracia and Hernández 1980) and confirmed that the pottery ' $\mathrm{H}$ ' is slightly different from pottery ' $\mathrm{G}$ ' or ' $\mathrm{P}$ ', although small differences between ' $G$ ' and ' $P$ ' could be observed. They concerned the $\mathrm{Fe}^{2+} / \mathrm{Fe}^{3+}$ ratio $(1.6 \pm 0.4$ for ' $\mathrm{G}$ ' and $0.3 \pm 0.2$ for ' $\mathrm{P}$ ') and the number of $\mathrm{Fe}^{2+}$ sites (one $\mathrm{Fe}^{2+}$ site for all but one of the set ' $\mathrm{P}$ ', and two $\mathrm{Fe}^{2+}$ sites for set ' $\mathrm{G}$ ' and for the ' $\mathrm{P}$ ' sample with the highest $\mathrm{Fe}^{2+}$ content in its group). These differences between ' $\mathrm{P}$ ' and ' $\mathrm{G}$ ' can be related to the firing conditions strongly reducing atmosphere for ' $G$ ' and slightly for 'P' (Bouchez et al. 1974).

It can be assumed that a ceramic yields the same spectrum before and after refiring if the refiring was in the same atmosphere as the original firing, and the temperature during refiring was a little lower than the maximum reached during the original firing. This assumption allowed several authors (Riederer et al. 1979, Bakas et al. 1980, Takeda et al. 1979) to estimate the firing temperatures of ceramics by means of Moessbauer spectra obtained from the same sample after heating it at sequentially higher temperatures.

The MS parameters for pottery, if the thermal cycle and the kiln atmosphere are taken into account, depend on the chemical and mineralogical composition of the clay (Coey 1980, Maniatis, Simopoulos and Kostikas 1981).

In this work 'P', ' $\mathrm{G}$ ' and ' $\mathrm{H}$ ' were doubly refired: two hours of reducing were followed by two hours of oxidising refiring. The reducing medium was generated by covering the sherd with charcoal in an $\mathrm{N}_{2}$ atmosphere. The oxidation was accomplished by heating in air. Both treatments were performed at $850^{\circ} \mathrm{C}$ and $1000^{\circ} \mathrm{C}$, a time of 1 and $1 \frac{1}{2}$ hours, respectively, being necessary to reach these temperatures.

The salient features of the two experiments can be summarized as follows:

(a) After a reducing refiring at $850^{\circ} \mathrm{C}$ the colour of ceramics ' $\mathrm{P}$ ' and ' $\mathrm{G}$ ' changed from 
Table 2 XRD mineralogical analysis

\begin{tabular}{lccc}
\hline \hline & $\begin{array}{c}\text { ' } P \text { ' pottery } \\
\text { (5 samples) }\end{array}$ & $\begin{array}{c}\text { 'H' pottery } \\
\text { (5 samples) }\end{array}$ \\
\hline Quartz & $\mathrm{vh}$ & $\mathrm{vh}$ & $\mathrm{vh}$ \\
Micas & $\mathrm{h}$ & $\mathrm{h}$ & $\mathrm{vh}$ \\
Plagiocl. & $\mathrm{h}$ & $\mathrm{h}$ & $\mathrm{vh}$ \\
K-feldsp. & $\mathrm{h}$ & $\mathrm{h}$ & $\mathrm{vh}$ \\
Calcite & 1 & $\mathrm{~h}$ & - \\
\hline
\end{tabular}

$(\mathrm{vh}=$ very high, $\mathrm{h}=$ high, $1=$ low,$-=$ not found $)$

red or grey to blackish. The Moessbauer spectra of both could be superimposed and show a complete matching. The $\mathrm{Fe}^{2+} / \mathrm{Fe}^{3+}$ ratio obviously increases for ' $\mathrm{P}$ '; it also increases for ' $\mathrm{G}$ ' from 1.6 to 3.9 (figure 1). There is also an important reduction of the $\mathrm{Fe}^{3+}$ to $\mathrm{Fe}^{2+}$ in ' $\mathrm{H}$ ' samples. However, the Moessbauer spectra of refired ' $\mathrm{H}$ ' are different from ' $\mathrm{P}$ ' or ' $\mathrm{G}$ '.

(b) The behaviour after firing at $1000^{\circ} \mathrm{C}$ resembles that at $850^{\circ} \mathrm{C}$. The most interesting feature for both ' $\mathrm{P}$ ' and ' $\mathrm{G}$ ' is the formation of metallic iron during reduction, the characteristic sextet of which appears on the Moessbauer spectra (figure 2).

(c) For ' $\mathrm{P}$ ' and ' $\mathrm{G}$ ' samples (heated at $850^{\circ} \mathrm{C}$ and $1000^{\circ} \mathrm{C}$ ) a second treatment by oxidising refiring transforms almost all the $\mathrm{Fe}^{2+}$ to $\mathrm{Fe}^{3+}$, and also all the metallic iron previously formed at $1000^{\circ} \mathrm{C}$ (figures 1 and 2 ).

The ease of reduction of $\mathrm{Fe}$ at $850^{\circ} \mathrm{C}$ and reoxidation, plus the fact that the oxides of 'P' dissociate in the first cycle and reform to a greater extent after a second oxidation, probably indicate a firing temperature much below $850^{\circ} \mathrm{C}$.

As the Moessbauer spectra for samples ' $P$ ' and ' $G$ ' are the same both after reduction and subsequent oxidation, both groups of pottery were made from the same type of clay, and the original differences in colour are due to the different firing techniques.

The results of the mineralogical analysis by XRD are summarized in table 2 .

Large differences in the content of micaceous minerals and calcite are shown by ' $\mathrm{P}$ ' and ' $\mathrm{G}$ ' as compared with ' $\mathrm{H}$ ', which is richer in micas and does not contain calcite.

The diffractograms of ' $\mathrm{H}$ ' yield the peaks of illite and other micaceous minerals which transform into an oxide spinel phase around $850^{\circ} \mathrm{C}$ (Bradley and Grim 1961, Grim 1968, Antón 1973, Maggetti and Kuepfer 1978, Grimanis et al. 1980). In this work the oxidising refiring of ' $\mathrm{H}$ ' samples at $850^{\circ} \mathrm{C}$ produced a marked decrease of the peaks corresponding to micas, which disappear after a $950^{\circ} \mathrm{C}$ refiring.

The decomposition of calcite is completed at $c .850-900{ }^{\circ} \mathrm{C}$ (the $\mathrm{CO}_{2}$ dissociation pressure for $\mathrm{CaCO}_{3}$ is $381 \mathrm{~mm} / \mathrm{Hg}$ at $852^{\circ} \mathrm{C}$ and $760 \mathrm{~mm} / \mathrm{Hg}$ at $898^{\circ} \mathrm{C}$ (Weast, Selby and Hogman 1965)) even in a reducing atmosphere. Thus calcite is found only in ceramics fired at relatively low temperatures (Périnet 1960, Antón 1973, Maggetti and Kuepfer 1978, Grimanis et al. 1980). The diffractograms for samples ' $\mathrm{G}$ ' refired at $850{ }^{\circ} \mathrm{C}$ in a reducing atmosphere showed no calcite peaks although these were present in the unrefired sample. Therefore the firing temperature did not reach $850^{\circ} \mathrm{C}$.

The slightly higher calcite content in the 'grey pottery' ' $G$ ' can be ascribed to firing in a highly reducing atmosphere. In support of this hypothesis are the following facts: 

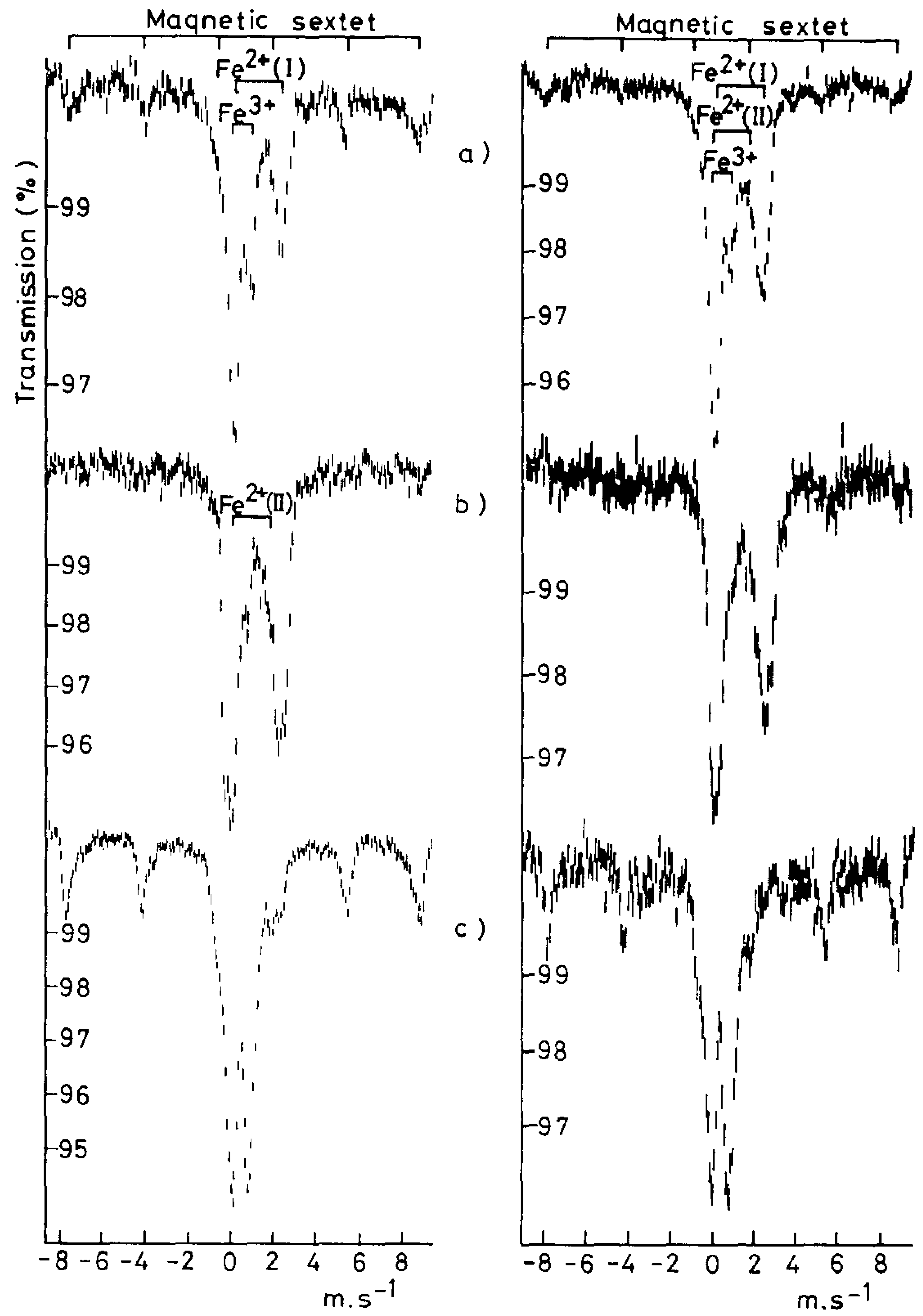

Figure 1 MS spectra of a 'P' (left) and a 'G' (right) sample before and after refiring at $850^{\circ} \mathrm{C}$. (a) Left: original ' $P$ ' sample (one site of paramagnetic $\mathrm{Fe}^{3+}$, one site of $\mathrm{Fe}^{2+}$, and magnetic sextet); right: original ' $G$ ' sample (one site of paramagnetic $\mathrm{Fe}^{3+}$, two sites of $\mathrm{Fe}^{2+}$, and magnetic sextet). (b) ' $P$ ' and ' $G$ ' samples refired in reducing atmosphere (one site of paramagnetic $\mathrm{Fe}^{3+}$, two sites of $\mathrm{Fe}^{2+}$, and magnetic sextet). (c) ' $P$ ' of ' $G$ ' samples twice refired: first reducing refiring as in (b), and then oxidising refiring (one site of paramagnetic $\mathrm{Fe}^{3+}$, one site of $\mathrm{Fe}^{2+}$, and magnetic sextet). 


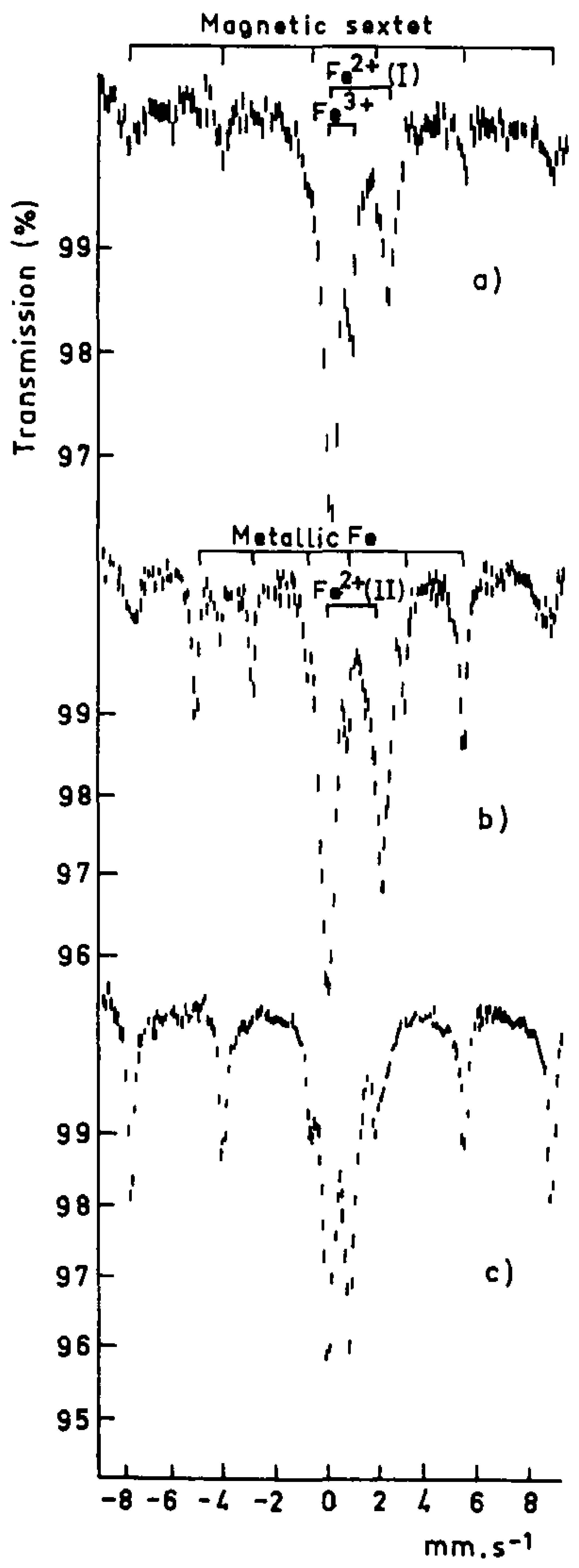

Finure 2 ins spectra of a ' $P$ ' sample before and after refiring at $1000^{\circ} \mathrm{C}$. (a) Original ' $P$ ' sample (one sitc' of paramagnetic $\mathrm{Fe}^{3+}$, one site of $\mathrm{Fe}^{2+}$, and magnetic sextet). (b) ' $P$ ' sample refired in reducing atmo. sph're (one site of paramagnetic $\mathrm{Fe}^{3+}$. two sites of $\mathrm{Fe}^{i+}$, metallic $\mathrm{Fe}$, and magnetic sextet). (c) ' $P$ ' sample wice refired: first reducing refiring as in (b), and then oxidising refiring (one site of paramagnetic $\mathrm{Fe}^{3+}$, onc site of $\mathrm{Fe}^{2+}$, and magnetic sextet). 


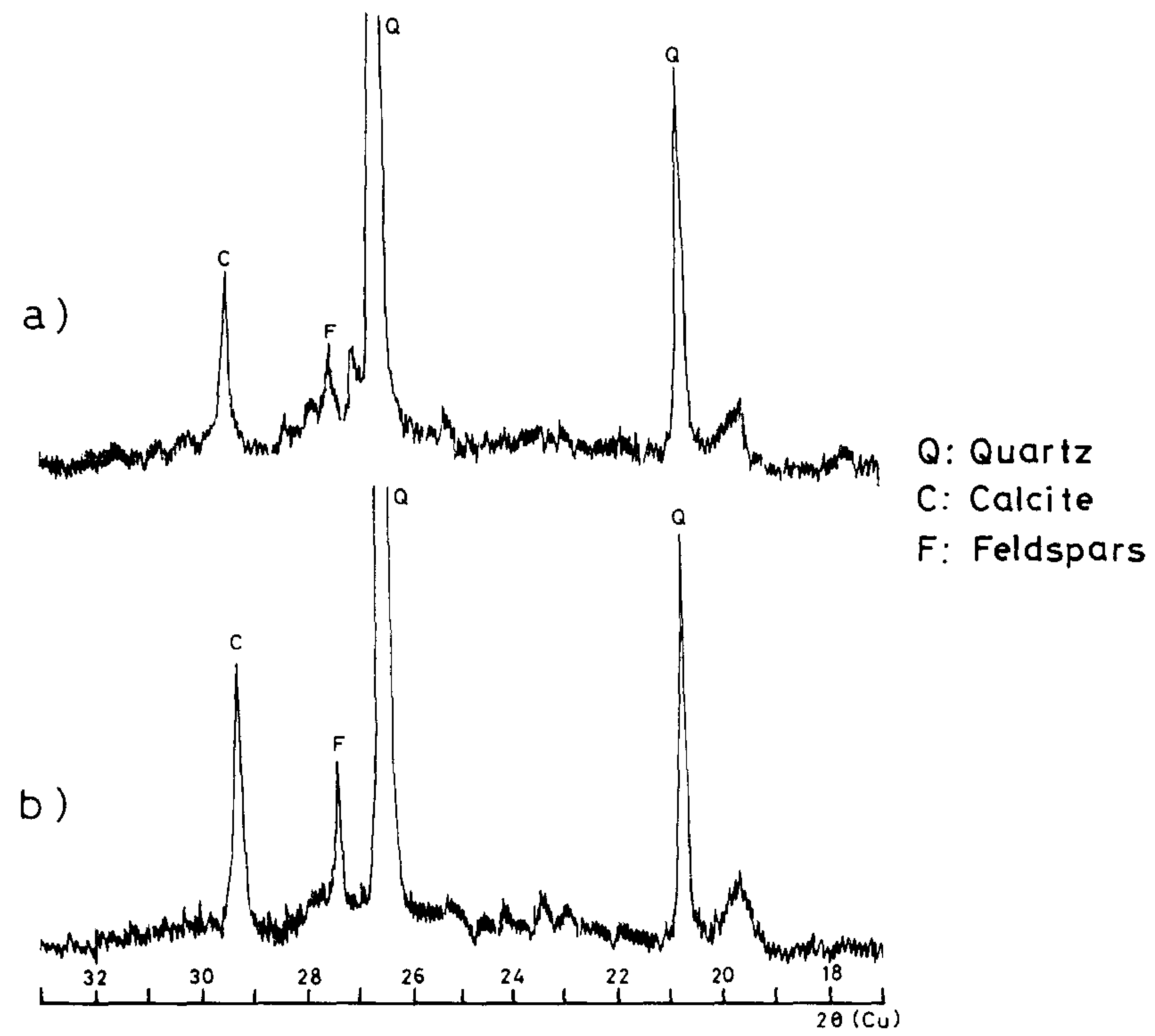

Figure $3 X R$ diffractograms of the matrix (a) and the core (b) of a ' $P$ ' ccramic with 'black core' and the highest $\mathrm{CaCO}_{3}$ content in its group.

(a) Some 'painted pottery' showed a 'black core' of greyish colour. The matrix shows a Moessbauer spectrum with a doublet of $\mathrm{Fe}^{2+}$ of very slight intensity, whereas in the core the intensity of the $\mathrm{Fe}^{2+}$ doublet is considerably greater. The increase of the $\mathrm{Fe}^{2+} / \mathrm{Fe}^{3+}$ ratio is due to the reduction of $\mathrm{Fe}^{3+}$ during firing by the organic matter present in the clay (Hamer 1975), with a corresponding evolution of $\mathrm{CO}_{2}$ which has to migrate outwards through the clay. The $\mathrm{CO}_{2}$ concentration in the core is thus greater than near the surface, thus retarding the decomposition of $\mathrm{CaCO}_{3}$. In addition, a fast and short firing can produce a temperature gradient between surface and core, causing a similar effect in the dissociation of calcite.

(b) XRD results show a greater concentration of $\mathrm{CaCO}_{3}$ in the black core than in the matrix (figure 3).

The $\mathrm{O}_{2}$ content of the kiln atmosphere is one of the factors influencing the $\mathrm{CaCO}_{3}$ concentration of the pottery. So, the greater content of $\mathrm{CaCO}_{3}$ in ' $\mathrm{G}$ ' could be due to a firing atmosphere much more reducing than that experienced by ' $\mathrm{P}$ '.

The above arguments are invalid if the $\mathrm{CaCO}_{3}$ crystallized in the sherd during its prolonged 


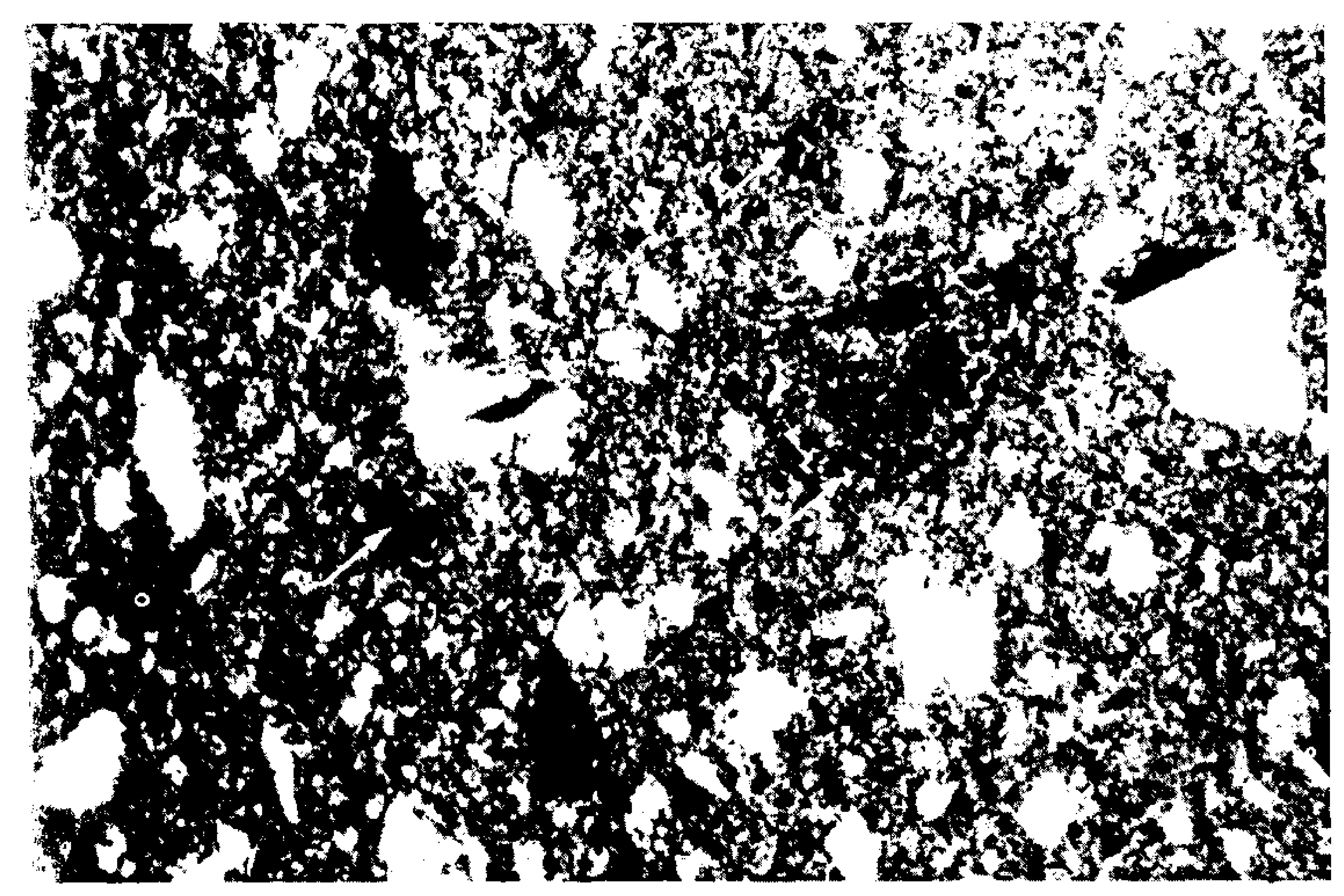

\section{$200 \mu \mathrm{m}$}

Figute 4 Microphotograph of a sample of thrown painted pottery ' $P$ '. Alizarin-tinted calcite clasts are marked.

burial (Prag et al. 1974, Maggetti and Kuepfer 1978, Grimanis et al. 1980, Périnet, de Contenson and Courtois 1980). However, petrographic evidence shows the calcite to be primary, not secondary. The calcite clasts have a uniform distribution into the clay matrix, and they are heteromorphous as the rest of the other minerals (see microphotograph in figure 4).

Samples of clay picked up at the excavation surroundings have a compatible mineral paragenesis to that of the sherds studied. This fact is obviously not conclusive in order to ascribe a common local origin to all the sherds under study.

\section{CONCLUSIONS}

(1) The high $\mathrm{Fe}^{2+} / \mathrm{Fe}^{3+}$ ratio found by MS in the 'grey pottery', and, probably, the high content of calcite imply that a strongly reducing atmosphere was used to give a grey colour to the ware (Antón 1973). The 'painted pottery' was fired under less reducing conditions in a badly ventilated kiln; probably the organic residues in the clay and/or a short time of final firing produced the 'black core' (Scott 1954, Matson 1969) exhibited by three of the five 'P' simples.

(2) A firing temperature below $850^{\circ} \mathrm{C}$ is indicated.

(3) The 'painted' and 'grey' pottery was made from the same type of clay and possibly from clay of the same provenance.

(4) The compositional differences between thrown-and hand-made pottery and the spread 
of data observed with the different techniques employed could have a two-fold origin: (a) the addition of non-plastics and/or the use of unsifted clay in the hand-made pottery; (b) the type of clay: calcareous clay in ' $P$ ' and ' $G$ ' pottery and non-calcareous clay in ' $H$ ' samples.

\section{ACKNOWLEDGEMENTS}

We are indebted to Fundación Juan March for financial support and to Dr $J$. Remesal who provided the sherds.

\section{REFERENCES}

Antón, G., 1973, X-ray diffraction analysis of Iberian ceramics from Valence, Spain, Serv' de Investigación Prehistórica, Diputación Provincial de Valencia, Serie de Trabajos Varios No. 45, pp. 1-46, Valence.

Bakas, Th., Gangas N. H., Sigalas, I. and Aitken, M. J., 1980, Moessbauer study of Glozel tablet $198 \mathrm{bl}$, Archaeometry 22 (1).69-80.

Bouchez, R., Coey, J. M. D., Coussement, R., Schmidt, K. P., Van Rossum, M., Aprahamian, J. and Deshayes, J., 1974, Moessbauer study of firing conditions used in the manufacture of grey and red ware of Tureng-Tepe, J. Phy's. (Paris) Colloq. 35 (C6), 541-546.

Bradley, W. F. and Grim, R. E., 1961, Mica clay minerals, in The X-ray identification and crystal structures of cla. minerals (ed. G. Brown), pp. 208-241, Norwich: Jarrold and Sons Ltd.

Coey, J. M. D., 1980, Clay minerals and their transformations studied with nuclear techniques: the contribution of Moessbauer spectroscopy, Atomic Energy Rev. 18 (1), 73-124.

Gancedo, J. R., Gracia, M. and Hernández, A., 1980, Moessbauer spectroscopy study of lberian pottery, J. Phys. (Paris) Colloq. 41 (C1), 401-402.

Grim, R. E., 1968, Clay mineralogy, 2nd ed., pp. 334-336, New York: McGraw-Hill.

Grimanis, A. P., Filippakis, S. E., Perdikatsis, B., Vassilaki-Grimani, M., Bosana-Kourou, N. and Yalouris, $\mathrm{N}$, 1980 , Neutron activation and $\mathrm{X}$-ray analysis of 'Thapsos Class' vases. An attempt to identify their origin, J. Archaeol. Sci. 7, 227-239.

Hamer, I., 1975, The potter's dictionary of materials and techniques, p. 26, London: Pitman Pub.

Maggetti, M. and Kuepfer, T., 1978, Composition of the terra sigillata from La Péniche (Vidy/Lausanne, Switzerland), Archaeometry 20 (2), 183-188.

Maniatis, Y., Simopoulos, A. and Kostikas, A., 1981, Moessbauer study of the effect of calcium content on iron oxide transformations in fired clays, J. Am. Ceram. Soc. 64 (5), 263-269.

Matson, F. R., 1969, Some aspects of ceramic technology, in Science in archaeology (eds D. Brothwell and E. Higgs), pp. 592-602, London: Thames and Hudson.

Périnet, G., 1960, Contribution of X-ray diffraction to evaluation of the firing temperature of a ceramic, Trans. 7th Intern. Ceram. Congress, London, 371-376.

Périnet, G., de Contenson, H. and Courtois, L., 1980, Mineralogical study of the 'Vaisselle Blanche' neolithic sherds from Ras-Shamra and Tell Ramad (Syria), C. R. Acad. Sc. Paris 290, Série D, 143-146.

Prag, A. J. N. W., Schweizer, I., Williams, J. LI. W. and Schubiger, P. A., 1974, Hellenistic glazed wares from Athens and Southern Italy: analytical techniques and implications, Archacometry 16 (2), 153-187.

Riederer, J., Wagner, U. and Wagner, F. E., 1979, Moessbauer study of firing conditions of ancient Egyptian ceramics with multicoloured layers, Radiochem. Radioanal. Letters 40, 319-328.

Scott, L., 1954, Pottery, in A history of technology, Vol. I (eds C. Singer, E. J. Holmyard, and A. R. Hall), pp. 376-412, Oxford.

Takeda, M., Kawakami, O., Kobayashi, H. and Tominaga, T., 1979, Estimation of firing tempetatures of ancient roofing tiles by Fe-57 Moessbauer spectroscopy, J. Phys (Paris) Colloq. 40 (C2), $483-484$.

Weast, R. C., Selby, S. M. and Hogman, Ch. D. (eds), 1965, Handbook of chemistry and physics, 46th ed., p. F-49. Ohio: The Chemical Rubber Co. 